\title{
Pengembangan Wirausaha Jamur Tiram Sebagai Agribisnis Prospektif Di Kampung TKI Desa Tanggulturus Kabupaten Tulungagung
}

\author{
Yushi Mardiana $^{1}$, dan Sumarji ${ }^{2}$ \\ ${ }^{1,2}$ Universitas Islam Kadiri \\ Email : ${ }^{1}$ yushimardiana@gmail.com, ${ }^{2}$ sumarji@ uniska-kediri.ac.id
}

\begin{abstract}
Oyster mushroom is one of the leading commodities of Tanggulturus village. Tanggulturus is known as the village of TKI (Indonesian Workers) because many of its citizens work as TKI. Knowledge and information about oyster mushroom cultivation techniques that are effective and efficient, depend on the availability of mushroom baglog from craftsmen outside the area, limited expertise in processing oyster mushrooms into products ready for consumption, and people do not have enough knowledge and skills in creating product packaging is a problem the principal experienced by the Tanggulturus community in the cultivation of oyster mushrooms. Activities carried out during July-August 2019. These activities include training and mentoring. Providing training to improve the knowledge and knowledge of citizens on the cultivation of oyster mushrooms. Exposure training and discussion, and assistance in the practice of making mushroom baglogs. Training and practice of processing oyster mushrooms into processed oyster mushroom chips with flavor variants. Training on packaging practice and marketing management. Donations to farmer groups in the form of baglog press tools to facilitate sustainable baglog production activities in the community. These training and mentoring activities are a means of transferring science and technology for the residents of Tanggulturus Village. This activity is also in the context of development in the field of oyster mushroom entrepreneurship in Desa Tanggulturus..
\end{abstract}

Keywords: TKI village, Entrepreneur, Oyster mushroom.

Abstrak

Jamur tiram merupakan salah satu komoditas unggulan desa Tanggulturus. Tanggulturus dikenal sebagai desa TKI (Tenaga Kerja Indonesia) karena banyak warganya bekerja sebagai TKI. Ilmu pengetahuan dan informasi tentang teknik budidaya jamur tiram yang efektif dan efisien, ketergantung pada ketersediaan baglog jamur dari pengrajin di luar daerah, keterbatasan keahlian dalam pengolahan jamur tiram menjadi produk siap konsumsi, dan masyarakat belum memiliki cukup pengetahuan dan keterampilan dalam mengkreasikan pengemasan produk merupakan permasalahan pokok yang dialami oleh msyarakat Tanggulturus dalam budidaya jamur tiram. Kegiatan dilakukan selama bulan Juli-Agustus 2019. Kegiatan ini meliputi pelatihan dan pendampingan. Pemberian pelatihan untuk meningkatkan ilmu dan pengetahuan warga terhadap budidaya jamur tiram. Pelatihan paparan dan diskusi, serta pendampingan praktik pembuatan baglog jamur. Pelatihan dan praktik pengolahan jamur tiram menjadi olahan keripik jamur tiram dengan varian rasa. Pelatihan praktik pengemasan dan manajemen pemasaran. Pemberian sumbangan kepada kelompok tani berupa alat press baglog untuk memfasilitasi kegiatan pembuatan baglog yang berkelanjutan di masyarakat.Kegiatan Pelatihan dan pendampingan ini menjadi sarana transfer IPTEK bagi warga Desa Tanggulturus. Kegiatan ini juga dalam rangka pengembangan di bidang wirausaha jamur tiram di Desa Tanggulturus.

Kata Kunci: Desa TKI, Wirausaha, Jamur Tiram. 


\section{Pendahuluan}

Jamur merupakan tumbuhan sederhana yang banyak dijumpai di alam bebas, dikatakan sebagai tumbuhan sederhana karena tidak berklorofil dan tidak melakukan fotosintesis. Jamur dapat tumbuh dengan mudah dibatang kayu atau tumpukan sampah organik. Beberapa jenis jamur yang telah dikenal petani Indonesia seperti jamur merang, jamur kuping, jamur shitake, jamur tiram, dan jamur lingzhi mempunyai nilai ekonomi yang tinggi untuk dikembangkan karena cara budidaya relatif mudah, tidak memerlukan lahan yang luas, dan prospeknya menjanjikan.

Sejak 3000 tahun yang lalu, jamur telah banyak dimanfaatkan sebagai bahan makanan. Di Cina, pemanfaatan jamur sebagai bahan obat-obatan sudah dimulai sejak 2000 tahun silam. Sebagai bahan pangan jamur menjadi salah satu sumber protein seperti Thiamine 2 (vitamin B1), Riboflavin (vitamin B2), Niasin, Biotin dan Vitmin C serta mineral (Anonim, 2019).

Jamur tiram atau dalam bahasa latin disebut Pleurotus sp. merupakan salah satu jamur konsumsi yang bernilai tinggi. Beberapa jenis jamur tiram yang biasa dibudidayakan oleh masyarakat Indonesia yaitu jamur tiram putih (P.ostreatus), jamur tiram merah muda (P.flabellatus), jamur tiram abu-abu (P. sajor caju), dan jamur tiram abalone (P.cystidiosus). Di alam liar, jamur tiram merupakan tumbuhan saprofit yang hidup dikayu- kayu lunak dan memperoleh bahan makanan dengan memanfaatkan sisa-sisa bahan organik.

Jamur tiram merupakan salah satu komoditas unggulan desa Tanggulturus. Tanggulturus merupakan desa yang terletak di kecamatan Besuki, Kabupaten Tulungagung, Jawa Timur. Wilayah Desa Tanggulturus terletak di dataran rendah dengan luas 254.009 ha. Secara administratif desa ini berbatasan dengan desa Tanggulkudung di sebelah utara, desa Keboireng di sebelah selatan, desa
Tanggulwelahan di sebelah timur, dan desa Sedayugunung di sebelah barat. Desa ini terdiri atas dua dusun, yaitu dusun Tanggul dan dusun Turus.

Salah satu fenomena sosial desa Tanggulturus yang cukup terkenal adalah julukan "desa TKI (Tenaga Kerja Indonesia) (Arif, 2017). Sebutan tersebut muncul karena sebagian warga usia produktif dari desa ini banyak yang mengadu nasib di negeri orang untuk menjadi TKI. Fenomena tersebut memberikan dampak positif sekaligus dampak negatif bagi warga.

Dampak positifnya adalah dari sisi kondisi ekonomi. Hampir semua warga desa Tanggulturus hidup layak dengan perekonomian yang cukup, serta dapat dikatakan memiliki persediaan modal untuk melakukan usaha mandiri (Rachman, 2018). Sedangkan dampak negatif timbul terutama bagi anak-anak TKI yang ditinggalkan orang tuanya bekerja di luar negeri. Pengasuhan dan pendidikan anakanak di desa ini diperankan oleh nenek atau kakek, bukan oleh orang tua.

Sehingga fenomena desa TKI bagaikan dua sisi mata uang yang saling bertolak (Purwaningsih, 2015). Satu sisi dapat mengangkat derajat ekonomi dan sosial masyarakat, tetapi sisi lain menyebabkan anak-anak sebagai generasi penerus tidak mendapat pola asuh, kasih sayang dan pendidikan yang optimal (Ariyanti, 2017). Realita itu pun bisa dipandang sebagai peluang sekaligus ancaman. Oleh karena itu, pendampingan yang bijaksana berkaitan dengan kegiatan ekonomi, pendidikan, dan sosial perlu dilakukan (Yuniastuti, 2014). Pendampingan disini dilakukan untuk meningkatkan pemahaman masyarakat bahwa perlu ada rencana jangka panjang yang harus ditata bersamaan dengan rencana jangka pendek dalam bidang pendidikan anak-anak, ekonomi produktif, dan sosial masyarakat.

Kegiatan ekonomi produktif yang dilakukan warga di desa ini didominasi oleh bidang pertanian dan bidang peternakan. 
Desa Tanggulturus memiliki lahan pertanian beririgasi teknis seluas 37.000 ha. Selain lahan pertanian beririgasi teknis, warga juga memiliki lahan pekarangan di sekitar bangunan rumah. Pada umunya lahan pekarangan warga digunakan untuk beternak. Selain menghidupkan peternakan di lahan pekarangan, beberapa warga juga memanfaatkannya untuk membangun kumbung jamur tiram.

Pemerintah desa Tanggulturus dan pemerintah Kabupaten Tulungagung bersama-sama sepakat membangun brand image desa ini sebagai sentra produksi jamur tiram Kabupaten Tulungagung. Salah satu faktor pendukung kegiatan wirausaha jamur tiram di desa Tanggulturus adalah adanya faktor modal usaha. Hingga saat ini, masyarakat secara umum beranggapan bahwa modal merupakan faktor terpenting untuk memulai kegiatan wirausaha.

Ketersediaan modal mandiri merupakan potensi dan peluang bagi warga desa Tanggulturus untuk mengembangkan wirausaha jamur tiram. Permasalahan pokok dalam pengembangan wirausaha jamur tiram di desa Tanggulturus ada empat hal. Pertama, terbatasnya ilmu pengetahuan dan informasi tentang teknik budidaya jamur tiram yang efektif dan efisien. Kedua, masyarakat pembudidaya jamur tiram di desa Tanggulturus sampai saat ini masih tergantung pada ketersediaan baglog jamur dari pengrajin di luar daerah mereka. Ketiga, masyarakat desa Tanggulturus memiliki keterbatasan keahlian dalam pengolahan jamur tiram menjadi produk siap konsumsi. Keempat, masyarakat belum memiliki cukup pengetahuan dan keterampilan dalam mengkreasikan pengemasan produk.

Kegiatan ini juga bertujuan memberikan pelatihan keterampilan dan pendampingan kepada masyarakat desa Tanggulturus tentang prospek wirausaha jamur tiram.

\section{Pelaksanaan Dan Metode}

Kegiatan dilakukan selama bulan Juli s.d Agustus 2019 di Desa Tanggulturus, Kecamatan Besuki, Kabupaten Tulungagung. Kegiatan ini meliputi pelatihan dan pendampingan.

Pelatihan tentang wirausaha jamur tiram dilakukan terhadap 30 warga. Pemilihan peserta pelatihan dilakukan berdasarkan rekomendasi dari pamong desa dengan pertimbangan pada semangat dan keinginan wirausaha. Kegiatan pelatihan meliputi pelatihan teknik budidaya jamur tiram yang efektif dan efisien, pelatihan teori pembuatan baglog jamur tiram, pelatihan praktik pembuatan baglog jamur tiram, dan pelatihan praktik pengolahan jamur tiram menjadi keripik jamur tiram dengan varian rasa sekaligus pengemasan dan manajemen pemasaran.

Kegiatan pendampingan dilakukan melalui diskusi interaktif yang difasilitasi oleh tim pengusul atau diskusi interaktif dengan pemateri-pemateri yang dihadirkan sebagai pendamping tim pengusul pada kegiatan pelatihan yang dilaksanakan. Kunjungan terhadap gubug jamur tiram mitra kelompok tani juga dilakukan untuk melihat keadaan budidaya jamur tiram yang telah dilakukan oleh warga.

\section{Hasil dan Pembahasan}

Awal kegiatan pengabdian dilakukan dengan acara pembukaan. Pembukaan dihadiri oleh pelaksana pengabdian dan perangkat desa Tanggulturus, Tulungagung. Pembukaan dilakukan di halaman balai desa Tanggulturus dan diikuti dengan baik oleh para peserta pelatihan Wirausaha jamur Tiram. 


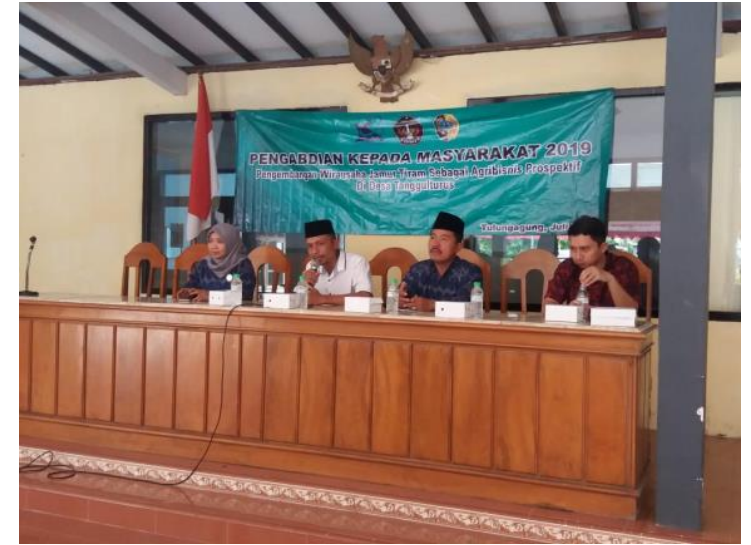

Gambar 1. Kegiatan pembukaan pelatihan yang dilakukan oleh perangkat desa Tanggulturus

Berdasarkan serangkaian kegiatan pengabdian kepada masyarakat yang dilakukan di Desa Tanggulturus, Kecamatan Besuki, Kabupaten Tulungagung, beberapa target capaian yang telah dicapai adalah sebagai berikut ini: Pertama adalah pemberian pelatihan untuk meningkatkan ilmu dan pengetahuan warga terhadap budidaya jamur tiram. Kegiatan ini berupa pemaparan materi serta diskusi tanya jawab antara pemateri dengan peserta pelatihan. Pemateri adalah pelaku usaha jamur tiram di wilayah Kediri Raya yang telah menjalankan usaha jamur tiram lebih dari 10 tahun dan memegang jabatan sebagai Ketua Kelompok Jamur Tiram seKarisidenan Kediri. Kegiatan ini diikuti masyarakat dengan antusias dan diskusi berjalan dengan baik.

Peserta mendapatkan berbagai informasi tentang potensi dan prospek budidaya jamur tiram. Berdasarkan ketersediaan bahan untuk media, budiaya jamur tiram memanfaatkan limbah organik yang melimpah, murah, dan mudah diperoleh di sekitar kita sehingga ketersediaan bahan penunjang budidaya tersedia terus menerus dan mudah didapat. Berdasarkan kebutuhan lahan, budidaya jamur tiram tidak memerlukan lahan yang luas yaitu untuk luasan kumbung $100 \mathrm{~m} 2$ bisa menampung \pm 7500 baglog, dengan estimasi pendapatan Rp. 200.000 per hari. Berdasarkan hasil panennya, produk jamur tiram dapat dimanfaatkan untuk menambah gizi atau menu serta dapat menambah pendapatan keluarga. Adapun limbah media dari sisa budidaya jamur tiram dapat digunakan untuk pupuk organik atau media pertumbuhan cacing.

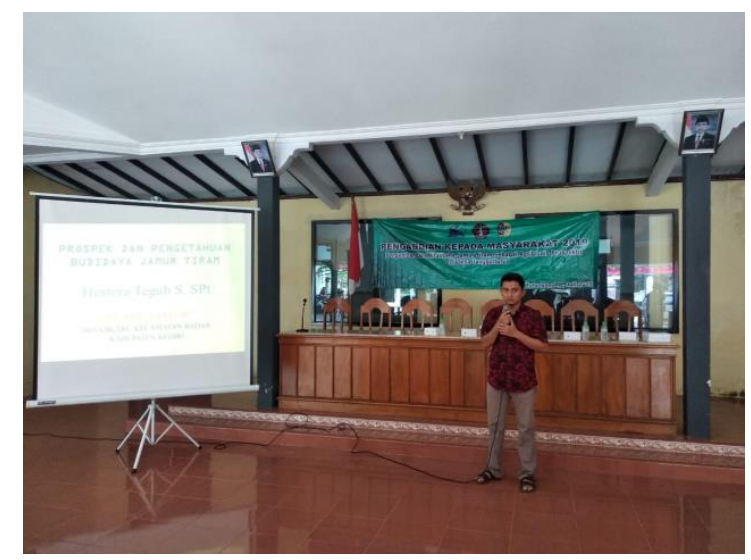

Gambar 2. Pelatihan budidaya jamur tiram oleh pemateri

Kedua dan ketiga adalah pelatihan dan praktik pembuatan baglog jamur. Kegiatan ini terdiri dari dua macam, yaitu pelatihan paparan dan diskusi, serta pendampingan praktik pembuatan baglog jamur. Peningkatan pengetahuan dan keterampilan masyarakat dalam pembuatan baglog jamur sendiri diharapkan memberi dampak signifikan bagi usaha budidaya jamur warga. Keterampilan ini akan menurunkan tingkat ketergantungan warga pada ketersediaan baglog dari perajin sekaligus menurunkan biaya produksi jamur tiram. Target luaran dari solusi kedua adalah meningkatnya ilmu pengetahuan, wawasan, dan keterampilan mitra kelompok tani jamur tiram desa Tanggulturus dalam pembuatan baglog jamur tiram. Setelah mengikuti pelatihan ini, mitra kelompok tani dapat mengurangi ketergantungan pada pembelian baglog jamur dari produsen baglog sehingga menurunkan biaya produksi jamur tiram.

Baglog adalah media untuk pertumbuhan jamur tiram. Pada umumnya jamur tiram yang dihasilkan pada tiap baglog adalah 30\%-35\% dari berat baglog pada tiap panennya. 


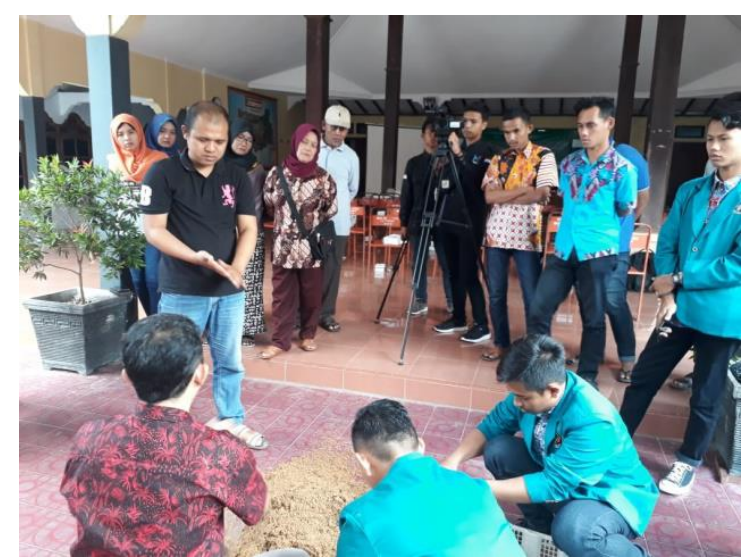

Gambar 3. Pelatihan pembuatan baglog jamur tiram

Komposisi baglog jamur tiram adalah serbuk kayu, tepung jagung, dedak, kapur, dan bibit jamur tiram. Langkah langkah pembuatan baglog jamur tiram diawali dengan cara mencampurkan serbuk kayu yang sudah diayak dengan tepung jagung, dedak, dan kapur, lalu menambahkannya dengan air secukupnya sehingga kelembababnnya mencapai 70$80 \%$ atau ditandai dengan tekstur yang bisa menggumpal saat dikepal tangan, tetapi tidak lembek.

Bahan-bahan komposisi media yang sudah tercampur rata kemudian dimasukkan ke dalam plastik berukuran 18x100x0,05 cm. Kemudian ditutup dengan cincin, kertas, dan diikat kuat dengan karet gelang atau penutup cincin.

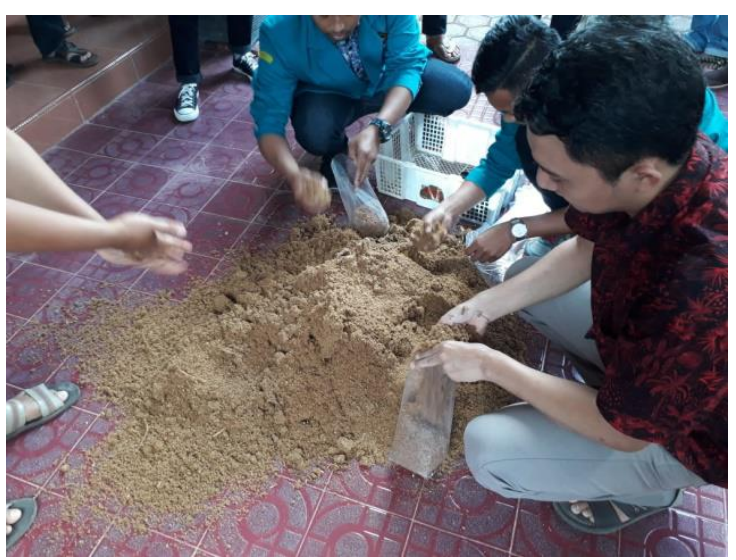

Gambar 4. Warga antusias mengikuti praktik pembuatan baglog

Bahan media baglog yang sudah siap dan rapi dalam plastik kemudian dikukus dengan suhu 90-100 0C selama 36 jam. Setelah pengukusan, media baglog didiamkan selama 5 jam untuk menunggu media tersebut menjadi dingin.

Setelah baglog didiamkan selama 5 jam, tutup baglog kemudian dibuka dan baglog diisi dengan bibit jamur yang telah dibeli dari pembibit. Satu botol bibit jamur berharga 25.000-30.000 rupiah dan dapat digunakan untuk mengisi sekitar 70 baglog jamur. Masa pertumbuhan miselium biasanya terjadi pada umur 7-10 hari setelah penanaman atau inokulasi. Kemudian masa panen optimal biasanya terjadi pada umru 40-60 hari setelah penanaman. Untuk menjaga pertumbuhan jamur tiram yang optimal, kelembaban kumbung atau lingkungan jamur tiram dijaga pada suhu 23-28 0C.

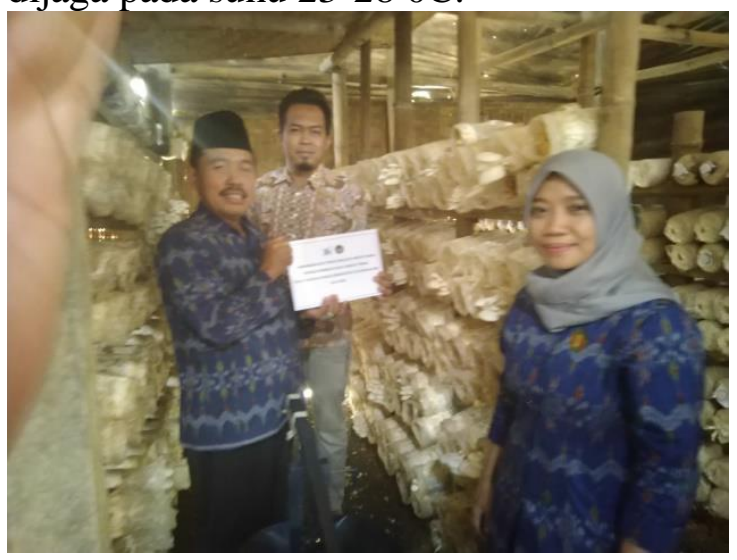

Gambar 5. Kunjungan ke kumbung jamur dan penyerahan bantuan alat

Keempat adalah pelatihan dan praktik pengolahan jamur tiram menjadi olahan keripik jamur tiram dengan varian rasa. Pengolahan jamur tiram belum dilakukan oleh masyarakat desa Tanggulturus. Pelatihan ini dapat memberikan keterampilan pengolahan jamur tiram bagi warga sehingga dapat meningkatkan nilai ekonomi dari penjualan jamur tiram yang dihasilkan. Target yang tercapai dari kegiatan ini adalah meningkatnya ilmu pengetahuan dan wawasan mitra kelompok tani terhadap pengolahan jamur tiram menjadi keripik jamur basah dan kering.

Warga pembudidaya jamur tiram di desa Tanggulturus sebelumnya hanya 
menjual produk segar jamur tiram secara langsung dengan kemasan sederhana. Jamur tiram hasil panen dari kumbung biasanya langsung dijual dengan cara dititipkan di warung-warung tetangga, atau jika dalam jumlah banyak bisa biasanya dibawa ke pasar atau dijual pada pengepul untuk disalurkan ke pasar yang lebih besar.

Kelemahan penjualan jamur tiram segar adalah harga jual yang rendah, daya simpan pendek, dan tingkat kerusakan yang tinggi. Harga jual jamur segar adalah 8.00013.000 rupiah per kilogram. Harga tersebut relatif murah bagi pembudidaya jamur di Tanggulturus.

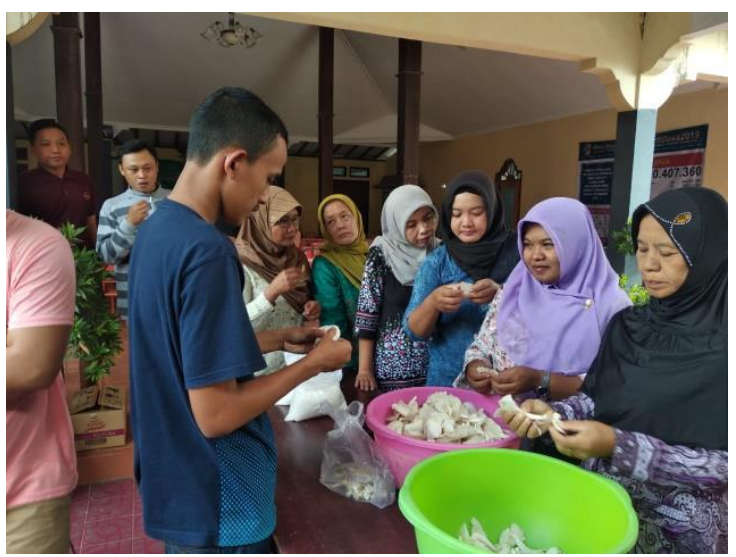

Gambar 6. Pelatihan pengolahan keripik jamur tiram (jamur tiram krispi)

Harga jamur tiram krispi dapat dipasarkan seharga 80.000 per kilogram. Jika dibandingkan dengan harga penjualan jamur segar, maka penjualan jamur krispi memberikan keuntungan yang lebih banyak dibandingkan dengan penjualan jamur segar.

Keuntungan lain dari penjualan jamur tiram dalam bentuk olahan jamur krispi adalah daya simpan yang lebih lama dan pemasaran yang lebih luas karena kerusakan produk dapat diminimalisir.

Pengolahan jamur tiram segar menjadi jamur tiram krispi diawali dengan memotong jamur tiram tersebut menjadi ukuran yang lebih kecil atau sekitar dua jari orang dewasa. Setelah itu, jamur yang telah dipotong-potong, dibersihkan dengan air bersih lalu merendamnya selama beberapa saat dalam air bersih. Sementara jamur tiram direndam air, pemanasan minyak goring dapat dilakukan agar ketika jamur siap digoreng, minyak tersebut sudah dalam keadaan panas dan optimal.

Persiapan menggoreng dilakukan dengan memcampurkan bubuk bumbu serba guna dengan tepung terigu. Jamurjamur yang telah direndam pada air bersih kemudian diambil sebagian dan ditiriskan setengah kering kemudian dimasukkan ke dalam campuran tepung bumbu tersebut. Jamur dipastikan terselimuti tepung pada semua bagiannya. Pada tahap penepungan ini, tidak boleh dilakukan peremasan pada jamur tiram karena nantinya akan terjadi kerusakan pada jamur tiram tersebut.

Penggorengan dilakukan setelah memastikan bahwa minyak goreng yang akan digunakan adalah dalam keadaan yang panas. Minyak goreng harus dalam keadaan panas supaya terjadi penggorengan secara sempurna dan tidak menyerap banyak minyak pada hasil jamur krispi nantinya. Jika jamur krispi akan dikemas dan dipasarkan untuk jangka waktu pemasaran yang cukup lama, maka penggorengan dilakukan sebanyak dua kali. Penggorengan kedua dilakukan setelah jamur yang telah digoreng satu kali didiamkan selama 12 jam terlebih dulu.

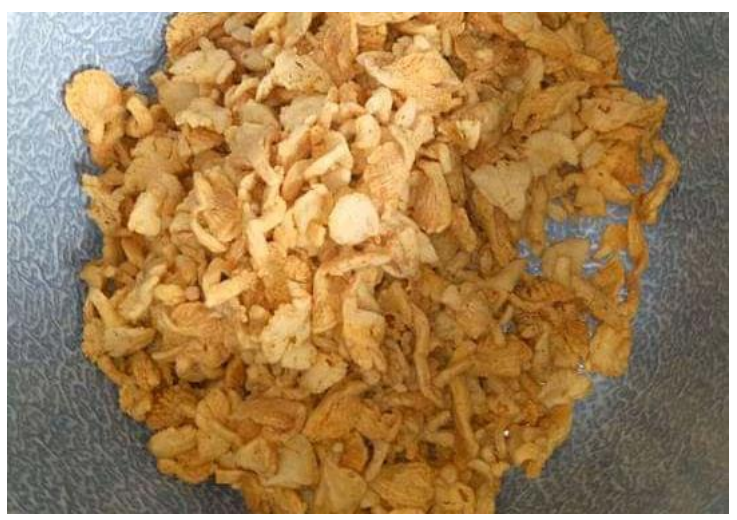

Gambar 7. Jamur tiram krispi hasil dari satu kali penggorengan.

Kelima adalah pelatihan praktik pengemasan dan manajemen pemasaran. Kegiatan pengemasan diakui dapat meningkatkan nilai jual suatu produk. Produk yang bagus dan didukung pengemasan yang bagus akan memberikan 
brand value tersendiri bagi calon konsumen. Target yang telah dicapai dari pelatihan ini adalah meningkatnya pengetahuan, wawasan, dan keterampilan mitra dalam mengemas produk sehingga menarik dan meningkatkan nilai jual.

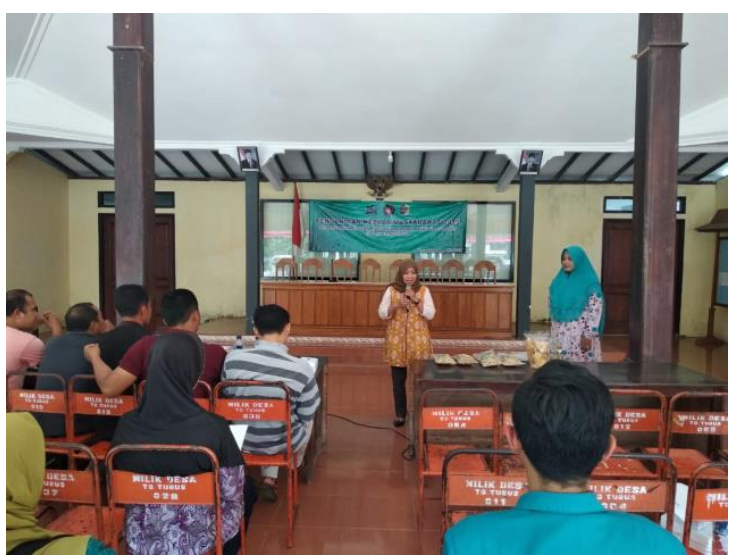

Gambar 8. Pelatihan strategi pengemasan produk dan pemasaran hasil olahan jamur tiram.

Strategi kemasan adalah adalah strategi pemasaran yang diciptakan, dikembangkan, dan dikendalikan sebagai bagian dari pemasaran atau penjualanKeberhasilan pemasaran suatu barang tidak hanya ditentukan oleh mutu barang serta usaha promosi yang dilakukan, tetapi juga oleh mutu penampilan kemasan itu sendiri. Kemasan suatu produk dituntut memiliki daya tarik yang lebih besar dibandingkan dengan barang yang dibungkus di dalamnya. Keberhasilan daya tarik kemasan ditentukan oleh estetik yang menjadi bahan pertimbangan sejak awal perencanaan bentuk kemasan, karena pada dasarnya nilai estetik harus terkandung pada keserasian antara bentuk dan penataan desain grafis tanpa melupakan kesan jenis, ciri, dan sifat barang yang diproduksi (Ferdinand, 2008)

Kegiatan pelatihan pengembangan wirausaha jamur tiram di desa tanggulturus ini ditutup dengan kegiatan pemberian bantuan alat press baglog bagi petani jamur tiram di desa tersebut. Terdapat dua petani jamur tiram di desa Tanggulturus yang telah membudidayakan jamur tiram, tetapi baglognya masih diperoleh dengan cara membeli pada pengrajin baglog di daerah lain.

baglog tersebut $\begin{gathered}\text { Pemberian bantuan alat press } \\ \text { bertujuan untuk }\end{gathered}$ meningkatkan kemandirian pembudidaya agar bisa membuat baglog sendiri tanpa tergantung pada pengrajin dari daerah lain. Ketergantungan baglog dari pengrajin daerah lain menyebabkan terhambatnya proses produksi jamur tiram. Hal itu disebabkan karena seringkali pengrajin baglog memproduksi baglog dalam jumlah terbatas sedangkan minat dari para pembudidaya jamur tiram cukup tinggi.

Selain itu, dengan kemampuan pembudidaya jamur tiram membuat baglog sendiri, diharapkan berdampak pada penurunan biaya produksi jamur tiram. Sehingga pada akhirnya, hal tersebut dapat memberi dampak peningkatan selisih biaya produksi dan penjualan hasil panen jamur tiram.

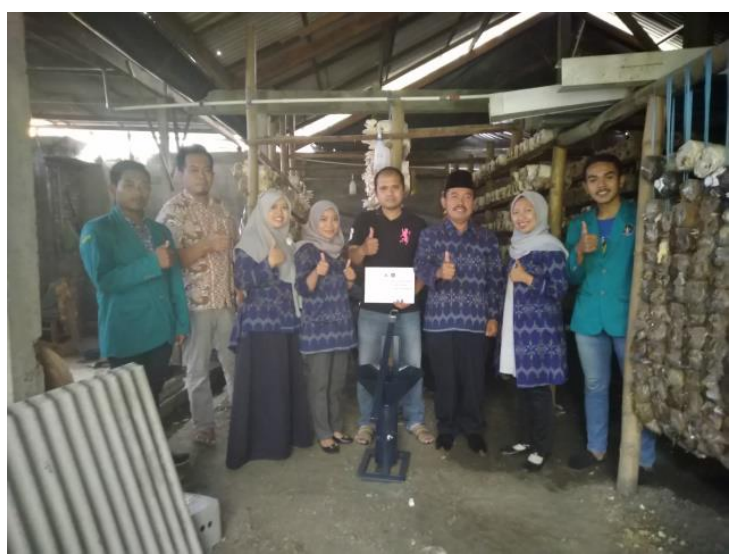

Gambar 9. Pemberian bantuan alat pres baglog pada mitra pelatihan

\section{Penutup}

\section{Kesimpulan}

Berdasarkan serangkaian kegiatan pengabdian kepada masyarakat dengan judul Pengembangan Wirausaha Jamur Tiram sebagai Agribisnis Prospektif di Kampung TKI, Desa Tanggulturus, Kabupaten Tulungagung yang telah dilaksanakan, dapat diambil beberapa kesimpulan sebagai berikut:

1. Masyarakat Desa Tanggulturus sangat antusias terhadap kegiatan pelatihan. 
2. Masyakarat terbuka wawasannya terhadap kegiatan wirausaha jamur tiram. Awalnya mereka hanya melakukan wirausaha dengan ilmu seadanya dari tetangga kemudian medapat tambahan informasi dari tim pengabdian tentang budidaya maupun pemasaran.

3. Masyarakat menjadi terbantu dalam meningkatkan keterampilan pembuatan baglog.

4. Masyarakat menjadi terbantu dalam meningkatkan keterampilan pengolahan hasil panen jamur tiram.

5. Masyarakat bisa membuat keripik jamur untuk dipasarkan jangka pendek (keripik jamur basah) dan jangka panjang (keripik jamur kering).

6. Masyarakat mulai mengemas produk olahan jamur tiram dengan kemasan yang bagus.

\section{Daftar Pustaka}

Anonim, 2018. Cara Budidaya Jamur Tiram (online) https://alamtani.com/cara-budidayajamur-tiram-putih/ diakses 20 Agustus 2019.

Arif, S. 2017. Lebih Dekat dengan Desa Tanggul Turus, Kampung TKI dengan Deretan Rumah Mentereng (online), (https://news.okezone.com/read/2017/0 3/26/519/1651546/lebih-dekat-dengandesa-tanggul-turus-kampung-tkidengan-deretan-rumah-mentereng), diakses 20 Agustus 2019.

Ariyanti, F. 2017. Perbandingan Gaji PRT Indonesia di 3 Negara (online) (https://m.liputan6.com/bisnis/read/293 6807/ini-perbandingan-gaji-prt-

indonesia-di-3negara?utm_expid=.t4QZMPzJSFeAiw 1BIOcwCw.0\&utm_referrer=https\%3A $\% 2 \mathrm{~F} \% 2 \mathrm{Fwww}$.google.com $\% 2 \mathrm{~F}$ diakses 20 Agustus 2019.

Ferdinand. 2008. Analisis Pengaruh Kemasan Terhadap Minat Beli Konsumen. Skripsi. Universitas Sanatha Dharma Jogjakarta.
Purwaningsih, S.S. 2015. Waspadai Dampak Keluarga TKI (online), (http://lipimedia/waspadai-dampakkeluarga-tki/10712), diakses 20 Agustus 2019.

Rachman, F.F. 2018. Jadi TKI di Taiwan Bisa Dapat Rp.10 Juta/ Bulan (online) (https://m.detik.com/finance/beritaekonomi-bisnis/d-4132901/jadi-tki-ditaiwan-bisa-dapat-rp-10-jutabulan) diakses 20 Agustus 2019.

Yuniastuti. 2014. Kehidupan Sosial Ekonomi TKI dan TKW serta Dampak Sosial Psikologis Pendidikan Anak. Jurnal Pendidikan Pancasila dan Kewarganegaraan, 27 (1): 65-70. 